\title{
PENGARUH BRIEF CONSELING FARMASIS DALAM PENINGKATAN PERILAKU DAN KEPATUHAN MINUM OBAT DI RSUD ULIN BANJARMASIN
}

\author{
Saftia Aryzki ${ }^{*}$, Amaliyah Wahyuni \\ Sekolah Tinggi Ilmu Kesehatan ISFI Banjarmasin \\ *: saftiaaryzki.h@gmail.com
}

\begin{abstract}
ABSTRAK
Hipertensi merupakan salah satu penyakit tidak menular. Sebanyak 1 milyar orang di dunia atau 1 dari 4 orang dewasa menderita penyakit ini. Bahkan, diperkirakan jumlah penderita hipertensi akan meningkat menjadi 1,6 milyar menjelang tahun 2025. Perilaku pasien dengan menerapkan terkontrolnya tekanan darah pasien maka akan membantu mencapai keberhasilan terapi pasien. Tujuan dari penelitian adalah untuk mengetahui Efek Brief Conseling Farmasis dalam Peningkatan Perilaku dan Kepatuhan Minum Obat di RSUD Ulin Banjarmasin. Penelitian yang dilakukan adalah penelitian kuasi-eksperimental menggunakan two group dengan metode pengambilan sampel dilakukan dengan metode counsecutive sampling dengan simple random yang memenuhi kriteria inklusi dan eksklusi. Sampel pada penelitian ini sebanyak 60 sampel dengan 30 sampel kelompok kontrol dan 30 sampel kelompok intervensi. Penelitian ini dilakukan di Poliklinik Penyakit Dalam Dalam RSUD Ulin dari Maret-Juni 2020. Teknik pengumpulan data yang digunakan pada penelitian ini dengan menggunakan kuisioner tingkat perilaku berobat, kuesioner kepatuhan MMAS (Morisky Medication Adherence Scale) dan EQ5D (Euro Quality of Life). Hasil dari penelitian ini adalah brief conseling farmasis dalam peningkatan perilaku, kepatuhan minum obat dan hasil terapi hipertensi di RSUD Ulin Banjarmasin memberikan efek yang positif bagi kelompok intervensi.
\end{abstract}

Kata Kunci: Hipertensi, Brief Counseling, Rumah Sakit

\section{ABSTRACT}

Hypertension is one of the deadliest diseases in the world. As many as 1 billion people in the world or 1 in 4 adults suffer from this disease. In fact, it is estimated that the number of hypertension sufferers will increase to 1.6 billion by 2025. Patient behavior by controlling the patient's blood pressure will help achieve the success of patient therapy. The purpose of this study was to determine the Brief Effect of Pharmacist Counseling in Improving Behavior and Adherence to at Ulin Hospital, Banjarmasin. The study was a quasi-experimental study using two groups. The sampling method was carried out by counsecutive sampling with simple random that met the inclusion and exclusion criteria. The sample in this study was 60 samples with 30 samples from the control group and 30 samples from the intervention group. This research was conducted at the Internal Medicine Polyclinic at Ulin Hospital from March-June 2020. The data collection technique used in this study was a questionnaire on the level of treatment behavior, the MMAS (Morisky Medication Adherence Scale) and EQ5D (Euro Quality of Life) compliance questionnaire. The results of this study were brief pharmacist 
Jurnal Insan Farmasi Indonesia, 3(2) Desember 2020 (394-404)

Saftia Aryzki

p-ISSN 2621-3184; e-ISSN 2621-4032

doi: $10.36387 /$ jifi.v3i2.482

counseling in improving behavior, medication adherence and the results of hypertension therapy at RSUD Ulin Banjarmasin which had a positive effect on the intervention group.

Keywords: Hypertension, Brief Counseling, Hospitas

\section{PENDAHULUAN}

Berdasarkan data Riset

Kesehatan Dasar (Riskesdas) pada tahun $2018^{1}$, prevalensi hipertensi berdasarkan hasil pengukuran pada penduduk umur $\geq 18$ tahun Kalimantan Selatan dengan peringkat nomor 1 di Indonesia. Hasil ini meningkat dari data pada tahun 2013 prevalensi hipertensi sebesar 30,4\% menjadi $44,1 \%$. Pendekatan yang lebih komprehensif dan intensif diperlukan guna mengubah perilaku sehingga pengontrolan tekanan darah secara optimal dapat tercapai ${ }^{2,3}$. Peranan penting dari farmasis untuk meningkatkan kesadaran pasien untuk mengubah perilaku pasien, dengan memberikan edukasi tentang penyakit yang sedang dialami kepada pasien dan keluarga, meningkatkan motivasi kepada pasien dalam menjalani pengobatan $^{4,5}$.

Metode konseling sudah banyak dilakukan, diantaranya pada program perilaku pasien dalam aktivitas fisik ${ }^{2}$. Penelitian yang telah dilakukan
Aryzki (2016) brief counseling "5A" oleh farmasis secara positif dapat mengubah kebiasaan aktivitas fisik secara signifikan $(\mathrm{p}<0,05)$ pada kelompok perlakuan pasien hipertensi di Poliklinik Penyakit Dalam Dalam RSUD H. Moch. Ansari Saleh Banjarmasin ${ }^{4}$. Penelitian lain juga menyebutkan, brief counseling "5A" oleh farmasis secara positif dapat mengubah tingkat kepatuhan secara signifikan $(\mathrm{p}<0,05)$ pada kelompok perlakuan pasien hipertensi di Poliklinik Penyakit Dalam Dalam RSUD H. Moch. Ansari Saleh Banjarmasin ${ }^{2}$.

\section{METODE PENELITIAN}

Penelitian ini merupakan penelitian kuasi-eksperimental menggunakan rancangan penelitian two group pretest and postest dengan pengambilan data pasien secara prospektif. Pasien dikelompokkan secara acak menjadi dua kelompok yang berbeda, yaitu kelompok yang intervensi dan kontrol yang diikuti selama satu bulan untuk mengamati 
perubahan perilaku pasien, kepatuhan minum obat dan hasil terapi. Teknik dalam memberikan konseling dengan konseling singkat (brief counseling) yang dijabarkan dalam strategi 5A yaitu, Assess, Advise, Agree, Assist, dan Arrange.

Penelitian ini dilakukan di Poliklinik Penyakit Dalam Dalam RSUD Ulin dari Maret-Juni 2020. Teknik pengumpulan data yang digunakan pada penelitian ini dengan menggunakan kuisioner. Kuesioner yang digunakan dalam penelitian ini adalah kuesioner tingkat perilaku berobat, kuesioner kepatuhan MMAS dan EQ5D.

Metode pengambilan sampel dilakukan dengan metode counsecutive sampling dengan simple random yang memenuhi kriteria inklusi dan eksklusi yang telah ditentukan oleh peneliti. Adapun kriteria inklusi adalah pasien berusia 18-65 tahun dan bersedia mengikuti penelitian. Sedangkan kriteria eksklusi adalah hamil, buta dan tuli, hanya keluarga pasien dan tidak hadir pada kunjungan kedua. Pengambilan sampel bersifat prospektif dengan jumlah sampel sebanyak 60 orang subjek yang mengikuti penelitian sampai akhir yang terbagi menjadi 30 pasien hipertensi yang mendapat intervensi (kelompok perlakuan) dan 30 pasien yang tidak mendapatkan intervensi (kelompok kontrol). Analisis statistik dan pengolahan data dilakukan dengan menggunakan program SPSS versi 16.0.

\section{PEMBAHASAN}

Penelitian telah memiliki Kelayakan Etik dengan nomor 59/IVRegRiset/RSUDU/20 pada tanggal 23 April 2020 yang dikeluarkan oleh Rumah Sakit Umum Daerah Ulin Kalimantan Selatan.

\section{Karakteristik Responden}

Karakteristik data subjek penelitian dapat dilihat pada tabel 1 .

Berdasarkan karakteristik pasien, pada kelompok kontrol dan kelompok perlakuan jenis kelamin laki-laki 18 orang $(53,0 \%)$ dan perempuan 16 orang $(47,0 \%)$. Hal ini sesuai dengan penelitian Aryzki (2019) yang menemukan bahwa jumlah penderita hipertensi perempuan lebih banyak daripada laki-laki. Ini dikarenakan perempuan mengalami menopause, yang pada kondisi tersebut terjadi perubahan 
hormonal, yaitu terjadi penurunan perbandingan estrogen dan androgen yang menyebabkan peningkatan pelepasan renin, sehingga dapat memicu peningkatan tekanan darah ${ }^{6}$.

Jumlah pasien berdasarkan kelompok umur pada kelompok kontrol dengan usia $<45$ tahun berjumlah 3 orang dan $>45$ tahun berjumlah 31 orang. Kelompok perlakuan dengan usia $<45$ tahun 3 orang $(8,9 \%)$ dan usia $>45$ tahun 31 orang $(91,1 \%)$. Semakin tua seseorang semakin besar risiko terserang hipertensi. Umur antara 40-60 mempunyai risiko terkena hipertensi, disebabkan arteri kehilangan elastisitasnya atau kelenturannya seiring bertambahnya usia ${ }^{7}$. Hal ini dikarenakan pada usia tua terjadi perubahan struktural dan fungsional pada sistem pembuluh darah perifer yang bertanggung jawab pada perubahan tekanan darah yang terjadi pada usia lanjut ${ }^{6,8}$.

$$
\text { Pendidikan pasien pada }
$$

kelompok kontrol dan kelompok perlakuan untuk pedidikan 0-9 tahun secara berturut-turut 18 orang dan 20 orang, kemudian diikuti pendidikan $>9$ tahun sebanyak 16 orang dan 6 orang. Pada kedua kelompok kontrol ataupun perlakuan pendidikan pasien sebagian besar sampai dengan SMP. Tingginya risiko terkena hipertensi pada pendidikan yang rendah, kemungkinan disebabkan kurangnya pengetahuan pada pasien yang berpendidikan rendah terhadap kesehatan dan sulit atau lambat menerima informasi (penyuluhan) yang diberikan oleh petugas kesehatan sehingga berdampak pada perilaku/pola hidup sehat. Pendidikan merupakan salah satu faktor yang mempengaruhi pengetahuan ${ }^{9}$. Semakin tinggi pendidikan seseorang maka akan berpengaruh terhadap pengetahuan yang baik pula. Berdasarkan penelitian Aryzki (2019) menyatakan bahwa ada hubungan Tingginya risiko terkena hipertensi pada pendidikan yang rendah, kemungkinan disebabkan kurangnya pengetahuan pada pasien yang berpendidikan rendah terhadap kesehatan dan sulit atau lambat menerima informasi (penyuluhan) yang diberikan oleh petugas kesehatan sehingga berdampak pada perilaku/pola hidup sehat ${ }^{6}$. Menurut 
Aryzki (2020) pendidikan merupakan salah satu faktor yang mempengaruhi pengetahuan, semakin tinggi pendidikan seseorang maka akan berpengaruh terhadap pengetahuan yang baik pula ${ }^{3}$. Tingginya risiko terkena hipertensi pada pendidikan yang rendah, kemungkinan disebabkan karena kurangnya pengetahuan pada seseorang yang berpendidikan rendah terhadap kesehatan dan sulit atau lambat menerima informasi (penyuluhan) yang diberikan oleh petugas sehingga berdampak pada perilaku/pola hidup sehat ${ }^{9}$.

Berdasarkan pekerjaan pasien, pasien dengan kelompok kontrol dan kelompok perlakuan dengan pekerjaan tinggi sebanyak 23 orang $(67,65)$ dan kelompok perlakuan 20 orang $(64,7 \%)$ sedangkan untuk pekerjaan rendah 11 orang $(32,35 \%)$ dan 14 orang $(58,9 \%)$. Berdasarkan penelitian Aryzki (2016) menunjukkan bahwa ada hubungan yang bermakna antara pekerjaan dengan tekanan darah $(\mathrm{p}=0,000)^{4,5}$. Pembagian kategori pekerjaan ini didasarkan pada tingkat stres yang didapatkan oleh pasien dari pekerjaan pasien. Stres dalam bekerja dapat meningkatkan resistensi pembuluh darah perifer dan curah jantung yang menstimulasi aktivitas saraf simpatis untuk pengeluarkan hormon adrenalin yang menyebabkan jantung berdenyut lebih cepat dan menyebabkan penyempitan pembuluh darah perifer yang dapat mengakibatkan terjadinya peningkatan tekanan darah ${ }^{7}$. Hasil dari uji analisis yang dilakukan pada data karakteristik pasien hipertensi dapat dilihat bahwa antara kelompok kontrol dan perlakuan diperoleh tidak ada perbedaan yang signifikan $(p>0,05)$ pada jenis kelamin (1,000), usia $(0,951)$, pendidikan $(0,461)$ dan pekerjaan $(0,024)^{2,6}$.

\section{Penilaian Data Awal}

Penilaian data awal penelitian diperlukan untuk melihat apakah kondisi sampel dari kelompok kontrol dan kelompok perlakuan sebelum mendapatkan intervensi dari farmasis memiliki persamaan atau perbedaan ${ }^{3}$.

Data awal untuk kedua kelompok harus sama agar dapat terlihat dengan jelas pengaruh dari pemberian intervensi konseling terhadap kelompok perlakuan. Gambaran data awal tersebut maka dilakukan uji perbandingan data awal 
(baseline) antara kelompok kontrol dan kelompok perlakuan ${ }^{3,6}$. Pada afektif berbeda dengan variabel lain yaitu terdapat perbedaan bermakna antara kelompok perlakuan dengan kontrol $(p<0,05)$. Hal ini tidak menjadi masalah dalam penelitian ini, karena banyaknya variabel yang diamati dan juga nilai signifikansi menunjukkan antara kelompok kontrol dan kelompok perlakuan berbeda signifikan $(\mathrm{p}<0,05) \quad$ lebih banyak dibandingkan yang tidak berbeda signifikan $(\mathrm{p}>0.05)$.

\section{Perilaku Pasien}

Perubahan perilaku pasien akan terjadi sejalan dengan proses yang awalnya tidak tahu menjadi tahu (kognitif), yang awalnya tidak mau menjadi mau (afektif), dan yang awalnya tidak bertindak menjadi bertindak (psikomotorik). Perubahan perilaku pasien dari perilaku yang buruk ke perilaku yang baik selama pengobatan menunjukan bahwa pengetahuan pasien tentang hipertensi dan pengobatannya memegang kesejahteraan yang sangat penting untuk mewujudkan perilaku yang menunjang pencapaian tujuan terapi. Pengukuran perubahan perilaku dapat dilakukan dengan menggunakan kuesioner tingkat perilaku yang terdiri dari tiga domain yaitu kognitif, afektif, dan psikomotorik ${ }^{2}$.

Pada tabel 3, peningkatan skor tingkat perilaku kelompok perlakuan meningkat lebih signifikan ini menunjukkan bahwa perubahan perilaku pasien untuk mencapai target terapi yang diharapkan dapat tercapai secara tidak langsung dengan memberikan brief counseling. Pada penelitian sebelumnya yang dilakukan oleh Aryzki (2016) brief counseling juga dapat memberikan pengaruh positif terhadap perubahan perilaku pada pasien hipertensi ${ }^{3}$.

Domain kognitif (domain pengetahuan) memegang peranan penting dalam perubahan perilaku. Perilaku yang didasari oleh pengetahuan atau kognitif akan bertahan lebih lama. Sedangkan sikap atau afektif adalah kesiapan dan kesediaan seseorang untuk melakukan suatu tindakan yang didasari atas pengetahuan yang dimiliki ${ }^{10}$.

Pada tabel 3, domain kognitif dan afektif tidak mengalami perbedaan yang signifikan $(p>0,05)$. Hal ini dikarenakan pada kelompok perlakuan 
domain kognitif meningkat karena pemberian konseling pengetahuan tentang hipertensi dan terapinya dari farmasis, sementara pada kelompok kontrol domain kognitif meningkat karena kemungkinan pasien mendapat pengetahuan tentang hipertensi dan terapinya dari luar (selain farmasis) seperti pengetahuan dari klinisi yang menangani pasien tersebut atau dari media lain seperti dari iklan, surat kabar, penyuluhan kesehatan, dan sumber informasi lainnya ${ }^{2}$.

Pada domain psikomotorik mengalami peningkatan yang signifikan $(\mathrm{p}<0,05)$ yang artinya terdapat perbedaan yang bermakna antara kelompok kontrol dan perlakuan. Psikomotorik adalah tahap akhir dari perubahan perilaku yang didasari oleh pengetahuan yang didapat sehingga menimbulkan perubahan sikap yang positif dari tindakan yang dilakukan ${ }^{10}$. Peningkatan skor domain psikomotorik pada kelompok perlakuan ini disebabkan karena pengetahuan yang didapat dari konseling farmasis berupa pengetahuan tentang hipertensi dan terapinya dapat merubah sikap pasien menjadi positif. Jadi pada akhirnya pasien akan mengambil suatu tindakan untuk mengubah perilakunya menjadi lebih baik dalam menjalani terapi hipertensi. Pada kelompok kontrol perubahan psikomotorik kemungkinan besar disebabkan karena adanya tekanan atau keterpaksaan dan tidak didasari dengan pengetahuan dan kesadaran ${ }^{10}$.

Sejalan dengan hasil penelitian ini, penelitian yang dilakukan oleh Sushmita et al., (2010) bahwa konseling yang diberikan farmasis pada pasien hipertensi dapat meningkatkan kognitif, afektif, dan psikomotorik pasien ${ }^{11}$. Aryzki (2016) menjelaskan bahwa konseling yang diberikan farmasis pada pasien hipertensi dapat meningkatkan kognitif, afektif, dan psikomotorik pasien sehingga kesadaran pasien terhadap hipertensi dan pengobatannya menjadi lebih baik ${ }^{4}$.

\section{Kepatuhan Minum Obat}

Rendahnya kepatuhan dapat berdampak pada rendahnya outcome klinis. Terutama pada pasien dengan penyakit kronis seperti hipertensi. Penilaian ketidakpatuhan pasien rawat jalan dalam pengobatan hipertensi 
penting untuk mengetahui efektivitas pengobatan sehingga target terapi dapat tercapai dengan baik. Walaupun demikian, klinisi sering tidak menanyakan tentang kebiasaan pasien minum obat, bagaimana cara pasien minum obat, hal ini mungkin dikarenakan karena terbatasnya waktu sehingga informasi yang seharusnya dapat disampaikan tidak bisa disampaikan. Selain itu terkadang mereka menganggap ketidakpatuhan bukanlah hal yang penting sebagai penyebab rendahnya terkontrolnya tekanan darah. Salah satu cara untuk menilai kepatuhan pasien hipertensi dalam meminum obat adalah dengan menggunakan kuesioner Morisky Medication Adherence Scale $(\mathrm{MMAS})^{12,13}$.

Pada tabel 4, dapat dilihat nilai peningkatan kepatuhan kelompok kontrol dan kelompok perlakuan (Mean $\pm \mathrm{SD})$. Uji beda kepatuhan pada kunjungan pre-post dari kelompok perlakuan dibanding kelompok kontrol menggunakan Uji Mann-Whitney Test menunjukkan data yang signifikan $(p<0,05)$. Sehingga dapat disimpulkan bahwa intervensi yang dilakukan farmasis terhadap pasien hipertensi dapat meningkatkan kepatuhan pasien dalam minum obat sehingga dapat membantu pasien dalam mencapai keberhasilan terapi.

Penelitian yang dilakukan Aryzki (2015) menunjukkan bahwa dengan pemberian brief counseling " $5 \mathrm{~A}$ " dapat meningkatkan kepatuhan pasien dalam minum obat secara signifikan $(p>0,05)$. Beberapa alasan yang dikemukakan oleh pasien yang menyebabkan pasien tidak patuh dalam minum obat, diantaranya pasien mengaku lupa karena siang pada saat jam bekerja, pasien merasa sudah membaik karena tekanan darah sudah normal dan kurangnya pengetahuan tentang hipertensi serta ketidaktahuan pasien mengenai tujuan dari pengobatan ${ }^{4}$. Konseling tidak hanya meningkatkan kepatuhan, tetapi juga mengurangi komplikasi sebagai hasil dari ketidaktaatan terhadap pengobatan $^{2}$. 
Jurnal Insan Farmasi Indonesia, 3(2) Desember 2020 (394-404)

Saftia Aryzki

p-ISSN 2621-3184; e-ISSN 2621-4032

doi: $10.36387 /$ jifi.v3i2.482

Tabel 1. Karakteristik subyek penelitian pasien hipertensi di Poliklinik Penyakit Dalam Dalam RSUD Ulin

\begin{tabular}{lcccc}
\hline $\begin{array}{l}\text { Karakteristik } \\
\text { Pasien }\end{array}$ & \multicolumn{3}{c}{ Kelompok Kontrol } & \multicolumn{2}{c}{ Kelompok Perlakuan } \\
\cline { 2 - 5 } & $\begin{array}{l}\text { Jumlah } \\
(\mathrm{n}=30)\end{array}$ & $\%$ & $\begin{array}{l}\text { Jumlah } \\
(\mathrm{n}=30)\end{array}$ & $\%$ \\
\hline $\begin{array}{l}\text { Jenis Kelamin } \\
\text { Laki-laki }\end{array}$ & 10 & 29,41 & 14 & 53,0 \\
$\begin{array}{l}\text { Perempuan } \\
\text { Usia (tahun) }\end{array}$ & 20 & 70,59 & 16 & 47,0 \\
$<45$ tahun & 4 & 11,76 & 3 & 8,9 \\
$>45$ tahun & 26 & 88,23 & 26 & 91,1 \\
$\begin{array}{l}\text { Pendidikan } \\
\text { 0-9 tahun }\end{array}$ & 18 & 52,94 & 20 & 66,7 \\
$>9$ tahun & 12 & 47,06 & 10 & 20,0 \\
$\begin{array}{l}\text { Pekerjaan } \\
\text { Tinggi }\end{array}$ & 23 & 67,65 & 20 & 64.7 \\
Rendah & 11 & 32,35 & 10 & 58.9 \\
\hline
\end{tabular}

Keterangan: Pekerjaan Tinggi: Pegawai Negri Sipil (PNS), Swasta, Wiraswasta; Pekerjaan Rendah: Ibu Rumah Tangga (IRT), Buruh, Petani/Buruh Tani

Tabel 2. Data Awal Karakteristik Demografi dan Klinik Setiap Kelompok (Mean \pm SD) Pasien Hipertensi di RSUD Ulin

\begin{tabular}{lccc}
\hline \multicolumn{1}{c}{ Data awal (pre) } & $\begin{array}{c}\text { Kelompok } \\
\text { kontrol }(\mathrm{n}=30)\end{array}$ & $\begin{array}{c}\text { Kelompok perlakuan } \\
(\mathrm{n}=30)\end{array}$ & $p$ \\
\hline Kognitif & $2,59 \pm 1,02$ & $2,41 \pm 0,78$ & 0,408 \\
Afektif & $3,06 \pm 0,81$ & $2,02 \pm 0,86$ & $0,000^{*}$ \\
Psikomotorik & $2,65 \pm 0,98$ & $2,91 \pm 0,83$ & 0,240 \\
Kepatuhan Minum & $5,63 \pm 1,87$ & $6,45 \pm 1,31$ & 0,096 \\
Obat & & & \\
TD Sistolik & $159,12 \pm 15,05$ & $197,64 \pm 230,91$ & 0,588 \\
TD Diastolik & $95,88 \pm 12,82$ & $98,23 \pm 14,02$ & 0,626 \\
\hline
\end{tabular}

Tabel 3. Peningkatan tingkah perilaku kelompok kontrol dan kelompok perlakuan $($ Mean $\pm \mathrm{SD})$

\begin{tabular}{lccc}
\hline Tingkah perilaku & Kelompok Kontrol & Kelompok Perlakuan & $p$ \\
\hline Kognitif & $0,17 \pm 0,38$ & $0,11 \pm 0,32$ & 0,497 \\
Afektif & $0,05 \pm 0,23$ & $0,17 \pm 0,38$ & 0,135 \\
Psikomotorik & $-0,05 \pm 0,23$ & $0,17 \pm 0,57$ & $0,033^{*}$ \\
\hline
\end{tabular}

Tabel 4. Peningkatan kepatuhan kelompok kontrol dan kelompok perlakuan (Mean $\pm \mathrm{SD})$

\begin{tabular}{lccc}
\hline & Kelompok Kontrol & Kelompok Perlakuan & $p$ \\
\hline Kepatuhan & $0,24 \pm 0,78$ & $0,87 \pm 1,03$ & 0,033 \\
\hline
\end{tabular}


Jurnal Insan Farmasi Indonesia, 3(2) Desember 2020 (394-404)

Saftia Aryzki

p-ISSN 2621-3184 ; e-ISSN 2621-4032

doi: 10.36387/jifi.v3i2.482

\section{KESIMPULAN}

Kesimpulan dari penelitian ini adalah brief conseling Farmasis dalam Peningkatan Perilaku, dan Kepatuhan Minum Obat di RSUD Ulin Banjarmasin memberikan efek yang positif bagi kelompok intervensi.

\section{UCAPAN TERIMA KASIH}

Diberikan kepada Kementrian

Pendidikan dan Kebudayaan yang telah memberikan dana hibah penelitian dan RSUD Ulin Kalimantan Selatan yang telah menjadi tempat penelitian.

\section{DAFTAR PUSTAKA}

1. Riskesdas, 2018, Laporan Penelitian Riset Kesehatan Dasar, Badan Penelitian dan Pengembangan Kesehatan Departemen Kesehatan RI, Jakarta.

2. Aryzki, S., Alfian, R., Akrom. Pengaruh Brief Counseling Terhadap Kepatuhan Minum Obat Pada Pasien Hipertensi Rawat Jalan Di Poliklinik Penyakit Dalam RSUD H. Moch. Ansari Saleh Banjarmasin Pada Bulan April-Juni 2015. Yogyakarta : Program Pasca Sarjana Univiversitas Ahmad Dahlan, 2015.

3. Aryzki, S., \& Wahyuni, A. (2020). Penilaian Data Awal Penerapan Brief Conseling Farmasis Dalam Peningkatan Perilaku, Kepatuhan Minum Obat, Hasil Terapi Dan Kualitas Hidup Pasien Hipertensi Di Rsud Ulin Banjarmasin. Jurnal Ilmiah Ibnu Sina, 5(2), 335-344.
4. Aryzki, S., \& Alfian, R. (2016). Pengaruh Brief Counseling Terhadap Aktifitas Fisik pada Pasien Hipertensi Di RSUD Dr. H. Moch Ansari Saleh Banjarmasin. Jurnal Sains Farmasi \& Klinis, 3(1), 84-90.

5. Sander, D. Borgsteede, Marjan J. Westerman, and Jacqueline G. Hugtenburg.,2011. Factors related to high and low levels of drug adherence according to patients with type 2 diabetes. int $J$ Clin Pharm. October; 33(5): 779-787.

6. Aryzki, S., Ayuchecaria, N., Sari, Ana Khumaira (2019). Pengaruh Brief Counseling Farmasis Terhadap Aktivitas Fisik Dan Hasil Terapi Pasien Hipertensi Rawat Jalan Di Poliklinik Penyakit Dalam RSUD Ulin Banjarmasin. Jurnal Ilmiah Manuntung., 5(1), 30-37, 2019

7. Sekhar, S.M., Samiya, N., Tintu, S.J., Saraswathi, 2011, Legal Aspects of Patient Counseling: Need Of The Hour, ISSN: 2231-2781

8. James, P.A., Oparil, S., Carter, B., L., Cushman, W., C., Dennison, C., Handler, J., Lackland, D., T., LeFevre, M., L., Mackenzie, T., D., Ogedegbe, O., Smith, S., C., Syetkey, L., O., Taler, S., J., Townsend, R., R., Wright, J., T., Narya, A., S., Ortiz, E., 2014. Evidence-Based Guideline for the Management of High Blood Pressure in Adults Report From the Panel Members Appointed to the Eighth Joint National Committee (JNC 8). American Medical Association.

9. Permenkes, 2014, Peraturan Menteri Kesehatan Republik Indonesia Nomor 35 Tahun 2014 Tentang Standar Pelayanan Kefarmasian Di Apotek, Mentri Kesehatan RI, Jakarta 
Jurnal Insan Farmasi Indonesia, 3(2) Desember 2020 (394-404)

Saftia Aryzki

p-ISSN 2621-3184; e-ISSN 2621-4032

doi: 10.36387/jifi.v3i2.482

10. Notoatmodjo, S. 2014. Ilmu Perilaku Kesehatan. Jakarta: Rineka Cipta

11. Steinberg, K.L.; Roffman, R.A.; Carroll, K.M.; McRee, B.; Babor, T.F.; Miller, M.; Kadden, R.; Duresky, D.; and Stephens,R., 2005.Brief Counseling for Marijuana Dependence: A Manual for Treating Adults. DHHS Publication No. (SMA) 054022.Rockville, MD: Center for Substance Abuse Treatment, Substance Abuse and Mental Health Services Administration

12. Susanto, Y., Lailani, F., Alfian, R., Rianto, L., Febrianti, D. R., Aryzki,
S., \& Khairunnisa, N. S. (2019). Pemanfaatan Media Sosial Untuk Meningkatkan Kepatuhan Minum Obat Pasien Diabetes Melitus Rawat Jalan Di RSUD Ulin Banjarmasin. Jurnal Ilmiah Ibnu Sina, 4(1), 88-96.

13. Alfian, R., 2015, Layanan Pesan Singkat Pengingat untuk Meningkatkan Kepatuhan Minum Obat dan Kontrol Glikemik Pasien Diabetes Melitus di RSUD Dr. H. Moch. Ansari Saleh Banjarmasin, Media Farmasi, Vol.12 No.1 